\title{
A CONSTRUCÃO DA OBRA ÉPICA, DE ALFRED DÖBLIN
}

(Tradução de Celeste H. M. Ribeiro de Sousa*)

Em A Construção da Obra Épica, ${ }^{1}$ Alfred Döblin ${ }^{2}$ tece a gênese da épica moderna, ao refletir sobre as conseqüências da perda da linguagem oral - matéria-prima da épica antiga - na criação literária moderna. Nas palavras de Walter Benjamin, este ensaio é um documento da crise do romance, especialmente do roman pur, que se instaura com a reabilitação da literatura épica no começo do século XX.

I

\section{A OBRA ÉPICA FAZ O RELATO DE UMA SUPRA-REALIDADE}

Começo por perguntar: o relato é a forma básica do épico? Ou qual é de fato a característica determinante do épico? Conhecemos a do teatro, que é, pelo menos ao que parece, o diálogo.

(*) Professora do Departamento de Letras Modernas da FFLCH/USP.

(1) Döblin, Alfred. "Der Bau des epischen Kunstwerks", in: Die Neue Rundschau. Jahrgang IV. Jahrgang der freien Bühne, vol. 1. Berlin/Leipzig, ed. Fischer, 1929 , p. 527-551.

(2) Alfred Döblin é escritor alemão (1878-1957), um dos teóricos do Expressionismo, autor de, entre outros, Berlin Alexanderplatz e de uma trilogia sobre a conquista da América do Sul intitulada Amazonas. Döblin era médico psiquiatra de profissão. 
Pego um romance qualquer ${ }^{3}$ e leio: "Na época em que o coronel Spring von Springenau, depois de uma bem sucedida aposentadoria, se mudava do seu último posto em Rathenow, não para Wiesbaden, como a maioria de seus colegas de profissão, mas para Partenkirchen, Friederike tinha então acabado de fazer dezessete anos. Era primavera, das janelas da casa, em que a familia passava a morar, avistavam-se as montanhas bávaras para além dos telhados e, dia após dia, logo no café da manhã, o coronel, diante da mulher e dos filhos, louvava como uma grande sorte poder, ainda em anos vigorosos, mal tinha feito os sessenta, livre de compromissos profissionais, longe da poluição e da apatia da cidade grande, entregar-se à vontade ao desfrute da natureza, como sempre havia desejado desde a juventude." Não há dúvida que, aqui, se faz algo parecido com um relato. Algo parecido.

Apanho um jornal diário e lá está nas notícias locais: "Acidente de moto com dois funcionários da polícia. Hoje cedo, dois funcionários do posto de polícia da rua Wrangel bateram a moto contra um caminhão de lixo. Um deles, o primeiro sargento de polícia Wichert, de vinte e cinco anos de idade, fraturou a clavícula; o outro, o policial Willy Wolf, de vinte anos, sofreu graves ferimentos na cabeça e teve traumatismo craniano. Ambos foram levados ao hospital em Friedrichshain". Isto também é um relato, também é feito no imperfeito. ${ }^{4}$ Evidentemente o primeiro relato diferencia-se do segundo pelo fato de que este é um relato verdadeiro, informa o que aconteceu, enquanto o primeiro texto apenas imita um relato. $\mathrm{O}$ coronel Spring von Springenau, com certeza, não louvava em todos os cafés da manhã, como uma grande sorte, poder entre-

(3) Alfred Döblin refere-se ao romance Therese. Chronik eines Frauenlebens, de Arthur Schnitzler (1862-1931), que acabara de ser publicado (1928) pela editora Fischer.

(4) Döblin refere-se, é claro, ao tempo verbal do imperfeito usado no texto original em alemão. O tempo verbal do imperfeito alemão nem sempre pode ser traduzido pelo imperfeito do indicativo português, como neste caso, por exemplo. 
gar-se agora à natureza e duvido também que Friederike tivesse dezessete anos. Talvez a moça nem se chamasse Friederike e tivesse apenas dezesseis anos. Sem dúvida, são afirmações em que também não acredito, tanto mais que me são apresentadas na forma verbal do imperfeito. Mas isso é uma coisa que todos nós sabemos: que este coronel não louvou logo no café da manhã ter tido uma grande sorte em poder entregar-se à natureza, e qualquer leitor sabe que Friederike absolutamente não tinha dezessete anos, é o próprio autor que assim escreve, e apesar disso - o escritor escreve e nós aceitamos! Qual é realmente o objetivo? O homem não engana ninguém com o seu relato, também não quer enganar; entretanto, imita um relato verdadeiro. Por si só já sou contra imitações; gostaria, no entanto, de atinar com o sentido de uma tal imitação. E também não duvido que alguém sensato e calmo, ao ler na primeira página do jornal notícias do dia, redigidas no imperfeito, perceba, com razão, que, de repente, há no jornal um relato elaborado de maneira semelhante àquela mencionada acima, e que, obviamente, reconheça que a realidade foi prejudicada e que, com razão, considere essa afetação um assunto pueril, um abuso, e evite ler o jornal. O que dizer agora de um relato de romance, onde nem aquele que relata nem aquele que ouve o relato acreditam nele? É uma mentira com papéis divididos. Chamam-me a atenção, dizendo-me que é "arte" e eu já lamento ter que dizer que para mim, antes de mais nada, isso tem as características de uma mentira bem boba. Sopram-me energicamente ao ouvido: você é que é o bobo; no romance apenas se faz de conta que se relata, estamos com o velho Vaihinger ${ }^{5}$ estamos na esfera do "como se", em que não há necessidade de acreditar, o espectador no teatro também não acredita;

(5) Döblin refere-se aqui ao filósofo alemão "positivista idealista" Hans Vaihinger (1853-1933), que se ocupou da problemática da ficção numa obra intitulada Die Philosophie des Als-ob (A filosofia do como se), publicada em 1911 e que, em 1927, já se encontrava na $10^{a}$ edição. 
eventualmente, só as crianças e os camponeses caem nessa; tudo é só aparência, ilusão.

Ouço tudo isto. É a explicação certa, e aí temos nós em tamanho natural a nossa época pseudo-racionalista imbecilizada (há um racionalismo grandiloqüente, nossa época não é racionalista). Essa explicação através da aparência, da ilusão, do faz de conta, isso torna a literatura fria. Se deve ser considerado arte e forma básica do épico o fato de ambos, autor e leitor, fazerem de conta, e nós, desde o primeiro momento, sabemos disso, então não vale a pena escrever uma sílaba sequer.

Mas a questão da forma do relato é bem outra. Se a senhorita Amalie Lämmerkalb me ler o seu último romance e me contar alguma coisa, não, eu não acredito. Não acredito em nenhuma palavra dessa poetisa. Na realidade, isto está combinado entre nós. Mas como fica a situação quando Homero começa, quando Dante passa pelo inferno, quando Dom Quixote monta o seu cavalo e Sancho Pança o segue de burro? Será que ali também só se relata formalmente? Será?

Os antigos estetas dizem: claro, só se relata formalmente; Dom Quixote não está documentado e é claro que um burro andou pela Espanha; burros atravessam todas as paisagens, em todas as épocas, mas esse burro específico de Sancho Pança também não está documentado.

Mas, o que faz com que esse burro específico seja merecedor de crédito face a todos os outros burros? Cheguei aqui a um ponto bem fulcral. Existe evidentemente, além da esfera dos fatos históricos documentados, uma outra existência ou esfera de existência, passivel de ser relatada formalmente e no imperfeito, e tal relato exige de mim, do leitor ou do ouvinte também uma disposição para acreditar, de tal sorte que, nessas circunstâncias, valha novamente a pena escrever, já que agora se estabeleceu de novo entre autor e ouvinte um relacionamento sincero, assente em justificada confiança.

Agora o que eleva um caso inventado qualquer, apresentado em forma de relato, do âmbito do meramente imagi- 
nado e escrito a uma esfera verdadeira, àquela do relato especificamente épico, é a exemplaridade do caso e das personagens descritas, das quais se fala em forma de relato. Há aí fortes situações matriciais, situações elementares da existência do ser humano, que são apresentadas em relevo: são comportamentos elementares do ser humano que aparecem nesta esfera e, por já se terem manifestado mil vezes como verdadeiros, podem assim também ser relatados. Sim, essas figuras, que não são idéias platônicas, esse Odisseu, Dom Quixote, o peregrino Dante e essas situações humanas primordiais, no que se refere à primordialidade, à verdade e ao poder testemunhal, estão até acima das verdades comprovadas do cotidiano. E é assim que uma série de figuras, não um grande número, se eleva acima da realidade e, repetidamente, possibilita o poetar.

Não preciso dizer ainda, de modo particular, que atingir essa esfera exemplar e simples é o que separa o artista épico do escritor romântico, cujo trabalho com o romance é uma ocupação honestamente burguesa, utilitária, industrial. Um trabalho que imita a realidade sem penetrá-la, ou mesmo sem transpor algumas superficies dessa realidade. O artista verdadeiramente produtivo tem que dar dois passos: precisa aproximar-se bem da realidade, de sua concretude, de seu sangue, do seu cheiro, e, depois, tem que transpô-la; este é o seu trabalho específico. O primeiro passo já é o passo de qualquer bom escritor e pode-se constatar que qualquer autor épico é precedido por um bom escritor. Ademais, hoje também há por toda parte, inclusive no âmbito do épico, talentos poéticos bons e sofriveis, mas o escritor que aí se insere é fraco. Assim, naturalmente, nunca surgirá uma obra épica. Como, pois, se pretende transpor a realidade se, para isso, não forem tomadas medidas e se também, com freqüência, não se tem o poder de "agarrar" a realidade? Em segundo lugar, há bastantes (na verdade, não o suficiente ainda) romances descritivos e instrutivos, que só florescem com o trabalho do escritor, mas aí não há, por parte dos autores, ne- 
nhuma outra ambição, ou eles não sabem de mais nada além disso, tal qual o seu público. Mas, em terceiro lugar, ruins mesmo são aquelas composições poéticas de terceira categoria que entediam, visto que todos percebem não se tratar, de modo nenhum, de um genuíno autor épico, mas de um autor que absolutamente não ama a realidade, que não se esforça por captá-la, de um autor que fantasia e vive nas nuvens. Homero com certeza era cego, mas o foi somente a partir de seu trabalho poético - antes disso tinha uma vista agudíssima e objetiva, conheceu o solo grego e o troiano, bem como conheceu a sociedade como a palma da sua mão.

Acabo de mostrar onde, segundo penso, é permitido o uso da forma do relato na épica e gostaria de traçar uma hipotética linha histórica sobre o assunto:

É evidente que, nos primórdios da literatura, quer dizer, da humanidade em geral, apenas se relatava, relatava-se de maneira formal e, de fato, também se acreditava no que era relatado, e isso sempre. O acreditar fazia parte do relato, relatar significava "relatar a verdade". A realidade, o sonho e a fantasia eram, então, bem menos separados do que hoje, junte-se a isso a falta de esclarecimento, a curiosidade e o medo, que faziam as pessoas acreditarem constantemente em tudo o que era dito, que era relatado. Ainda hoje nos deparamos com este nebuloso estado primordial, quando contatamos pessoas e povos primitivos, e, quando, nos tribunais, há que jurar ou perjurar, ainda hoje encontramos em um certo número de pessoas simples esse estado primordial infantil em que se misturam sonho, fantasia e realidade. E eu gostaria de partir do princípio de que, na época em que Homero cantava, as coisas por ele relatadas ainda possuíam um alto grau de credibilidade: Odisseu esteve mesmo com Calipso na ilha, as sereias cantavam de fato e, aqui entre nós, hoje sabemos que nesses mitos e lendas há muito mais verdade, até mesmo verdade histórica, do que outrora se supunha. Atualmente, porém, a nossa situação é outra: não se acredita; realidade, 
fantasia e desejo são mantidos sóbria e rigorosamente separados.

E no que toca à arte, fizemos o seguinte: empurramos as obras de arte, do âmbito da realidade para o reino da ilusão, ou digamos simplesmente, para o reino do engano. Consideramos a vida como coisa séria e reservamos para a arte uma leveza bastante medíocre e cômica. Como pessoas sérias e ocupadas, permitimos que a arte tenha validade em nossos momentos descompromissados, das oito às dez da noite, no teatro, ou durante o dia no ônibus. Foi assim que fizemos com as coisas religiosas também. Instituímos para elas os domingos e feriados e estabelecemos um certo número de empregados para administrá-las. Ainda hoje se dispensa uma certa piedade às coisas. Só que, tanto na religião quanto na arte, algumas pessoas fazem desta situação uma leitura bem diferente daquela dos seus contemporâneos oficiais. Da mesma forma que o piedoso domingo não é a última palavra da religião, assim também, o velho Vaihinger não é a última palavra da arte. A arte é e será sempre uma coisa rara. Uma obra de arte age em dois sentidos: no do conhecimento (isso mesmo, no do conhecimento, para o pesar dos filósofos) e no da criação. E, assim, meu esboço histórico termina com o terceiro parágrafo sobre a arte:

As obras artísticas têm a ver com a verdade.

O artista épico, ainda hoje, pode fazer uso do relato com toda a seriedade.

\section{II}

\section{A obra Épica RECUSA A REALIDADE}

Depois de ter justificado o uso do relato no texto épico, abandono este ponto e, no que pretendo fazê-lo, ao dar mais uma olhada, fico surpreso, paro, e chego a uma outra conclu- 
são que contraria a primeira. Leio, então, algumas frases de Dom Quixote e vejo que o que aí se diz é - conscientemente uma inverdade, sem dúvida para os dois lados, para o autor e para o leitor! E, apesar disso, ou melhor, por isso mesmo, assim é que é, a forma do relato é a escolhida! Atino, de repente, com o "por isso mesmo". O autor escolhe a forma do relato, só permitida no âmbito dos assim denominados fatos, usa-a para os seus notórios não fatos, pois isso é agora algo altamente excitante e divertido, uma enorme dose de diversão. Aqui há uma inversão característica da arte numa época materialisticamente científica. Trata-se do fato, do fato magnífico e independente do livre fabular. O que é o fabular, o relatar maroto, descompromissado de não fatos, de notórios não fatos? É o jogo com a realidade, nas palavras de Nietzsche, uma gargalhada de superioridade em relação aos fatos, em relação à realidade como tal. Por isso, o conhecimento de que não é verdade e de que, apesar disso, o uso do relato é necessário. Aqui, alguém concorre com essa realidade sólida e firme como pedra, fazendo magias, soprando bolas de sabão com o mesmo material com que o criador do mundo fez toda terra, o céu e todos os animais com seus destinos. Estamos no campo muito soberbo e muito humano da livre fantasia.

A forma do relato mostra a vontade soberana do homem, pelo menos do autor, de brincar com a realidade, para o pesar do saber e da ciência. Então, tudo o que se pode imaginar, torna-se possivel, a força da gravidade é eliminada, todas as leis físicas são abolidas - mas, no mesmo momento, sabe-se que existe a força da gravidade, assim como todas as leis; porém, nós, nós podemos tudo, nós falamos na forma do relato de um mundo bem outro. A literatura é mais do que um sonho. O sonho também brinca com a realidade, mas, para a nossa sensibilidade, ainda está ligado fatal e incomodamente à realidade. $\mathrm{Na}$ literatura a sutileza e o desdém em relação à realidade são completos. Este é o enorme ganho em prazer que a forma do relato proporciona à fabulação, tanto para o autor quanto para o leitor. 
Coloque agora ao lado dessa leveza a deselegância e o peso da maioria de todos os romances, tanto os antigos quanto os recentes. Os autores, em sua ignorância, não percebem que tipo de instrumento lhes foi colocado nas mãos. São liquidados pelo racionalismo e pela era científica. Esta época deu o golpe fatal no poético. Os autores acreditam que precisam meter o nariz na realidade, ao invés de brincar com ela ou de tirá-la de si próprios. Acreditam, assim, terem dado o melhor de si, ao serem tanto quanto possivel autênticos e ao ficarem perto da natureza. Como se alguém fosse capaz disso. A natureza nem se deixa apalpar em suas entranhas e nem tampouco precisa de rebocadores. Há autores que se gabam de terem reproduzido de forma muito verdadeira e quase documental a história de uma época ou de uma familia, ou de uma pessoa, o mais autenticamente possivel, o mais próximo possivel da realidade. Talvez ainda com os métodos de um teórico, de um historiador. Se se comparar isto, se se comparar este esforço e este resultado com a esfera "suprareal", por mim primeiramente apontada como uma das colunas da forma do relato, e com a esfera do fantástico, da fabulação, como sendo a segunda coluna da forma do relato, quão mesquinhos e pobres e até burlescos se apresentam esses naturalistas, que acreditam ter de tomar ao pé da letra a forma do relato. Como acabei de mostrar, pode-se ver bem, agora, a relação entre ambas as esferas artísticas, que no épico estão entrelaçadas com a forma do relato: a esfera do fantástico e da fabulação não é nada mais do que a negação da esfera real, o que garante um jogo com a realidade - a esfera supra-real é a esfera de uma nova verdade e de uma realidade totalmente peculiar.

Portanto, agora pode-se falar novamente na forma do relato. Deste modo, esta forma torna-se de novo verdadeira na esfera da obra de arte épica e, aqui, não se trata mais de mentiras ou de quimeras: a literatura não é mais uma ocupação desonesta, confusa e desmerecedora, a literatura não é mais rebaixada a uma jogada subjetiva, e quando a verdadei- 
ra literatura épica utiliza o imperfeito e relata com soberba, é para mostrar que sabe quem é e que conhece o seu lugar e a sua posição na vida intelectual.

\section{III}

\section{A ÉPICA NÃO FALA DO PASSADO, REPRESENTA-O}

Com isso respondi à pergunta: o relato é a forma fundamental do épico? Respondi afirmativamente e com argumentos sobre quando e por quê o relato deve ser a forma fundamental do épico. Acrescento uma observação secundária. Falava do imperfeito e do relato, e isto pode levar a crer que a forma do passado deva ser a forma em que o autor épico deva construir a sua obra de arte. Isto nem se discute. É totalmente indiferente e uma questão puramente técnica, se o autor épico escreve no presente, no imperfeito ou no perfeito, ele vai trocar esses modi onde lhe aprouver. O que é decisivo, e observar isso não é secundário, é o seguinte: é incorreto o que muitas vezes se lê - que o dramaturgo oferece uma ação que se desenrola no presente, e o épico conta uma ação já ocorrida. Isto é superficial e ridículo. Para aquele que lê uma obra épica, os acontecimentos relatados começam a desenrolar-se no momento do agora, são vivenciados, tanto faz que estejam no presente, no imperfeito ou no perfeito; no épico, representamos as coisas tão no presente como o dramaturgo e é assim que também as aceitamos. Representamos ambos. Toda representação ocorre no presente, qualquer que seja a forma que assuma. A diferença entre o autor épico e o dramaturgo está no fato de que o dramaturgo deixa a ação desenrolar-se diante dos sentidos da visão e da audição, ao passo que o épico procura a fantasia para lugar de representação. Só este lugar intelectual, palco ou fantasia, distingue os dois tipos literários um do outro. Mais adiante, falarei ainda sobre o estreito contato entre o épico e o dramático. 


\section{IV}

\section{O CAMINHO PARA A ÉPICA FUTURA}

Depois de ter falado sobre o relato enquanto forma básica do épico, preciso fazer uma observação de ordem prática, que talvez possa surpreendê-lo, mas que deve oferecer aos autores uma informação, que contradiz o que foi dito antes, ou que parece contradizê-lo. Não recomendo usar a forma do relato como única e exclusiva na obra épica. Sabe-se que Homero, Dante, Cervantes, os três maiores nomes épicos, somente usaram a forma do relato, e todos os romances modernos na Alemanha, tanto quanto sei, só se articulam nesta forma. Eles representam relatando, contando. Não sou a favor disso. Há que observar aqui duas coisas distintas: de um lado, a obra de arte épica e, de outro, este recurso épico que é a forma do relato. Não está escrito em lugar algum que o épico tem apenas que relatar. No teatro antigo, também havia trechos que não tinham nada a ver com o desenrolar da ação, como, por exemplo, os coros. Shakespeare também permite, de quando em vez e de maneira tímida, que uma pessoa venha à frente da cortina para contar algo. Está certo. É igualmente um dogma, um dogma na iminência de ser abolido, o fato de que o teatro só se realiza no decorrer do diálogo. Constato com satisfação que o filme, a narrativa fotográfica, já penetraram experimentalmente no teatro, ${ }^{6}$ e que a forma do teatro dialogado já totalmente desgastada, do jogo das pessoas no palco, sem ter nada a ver comigo, me irrita.

Ficarão espantados se eu aconselhar os autores a serem resolutamente líricos, dramáticos e até reflexivos no trabalho épico. Mas insisto nisso. Não temos de comprometer a nossa liberdade no épico por causa de uma certa herança,

(6) Döblin refere-se às encenações de Erwin Piscator (1893-1966). As primeiras apresentações de passagens de filmes no palco ocorreram em 1924 durante a apresentação de Fahnen, de Alfons Paquet. Döblin escreveu uma resenha sobre esta representação e passou a adotar a técnica em suas obras. 
cuja tradição se apresenta como um dogma, e faremos do romance o que nos parecer correto. A Alemanha é o país de um realismo épico pedante e, aqui, uso realismo no seguinte sentido: você tem que relatar realidades ou pseudo-realidades. A França faz poesia com mais facilidade; há muito que é mais flexivel. Poucas regras artísticas estáveis pesam sobre o artista. O próprio artista elabora a maioria das regras artísticas. A obra de arte épica não é uma forma fixa; como o teatro, está em constante evolução e, para ser preciso, geralmente em oposição à tradição e aos seus representantes. Assim como o teatro hodierno se encontra entorpecido no diálogo das pessoas no palco - e o benefício da contemplação, da intervenção lírica ou escarnecedora, o beneficio da ação artística, livre e variada, bem como o do discurso direto, a nós dirigido, nos são negados, nós não participamos suficientemente daquilo que acontece no palco - o mesmo também acontece com o épico, onde a forma do relato se apresenta como uma cortina de ferro a separar leitor e autor. Aconselho o levantamento desta cortina de ferro.

Eu mesmo confesso: já rendi exacerbada homenagem ao relato, ao dogma da cortina de ferro. Nada me parecia mais importante do que a assim denominada objetividade do narrador. Admito que, ainda hoje, me alegro com a comunicação de fatos e com documentos, mas documentos, fatos. Sabem por quê? Aqui é o grande artista épico, a natureza, que me fala, e eu, o pequeno artista épico, estou diante dele e me alegro com a capacidade de meu irmão maior. E aconteceu-me que, ao escrever este ou aquele livro histórico, mal podia me conter para não copiar trechos inteiros, corridos, de documentos; sim, às vezes, sucumbia aos documentos, em êxtase, e dizia-me: melhor não posso fazer mesmo. E quando escrevia uma obra, ${ }^{7}$ que descrevia a luta de gigantes contra a grande

(7) Döblin refere-se a Berge, Meere und Giganten, iniciada em 1921 e terminada em 1923, e publicada em 1924. 
natureza, então quase não me podia conter para não copiar artigos geográficos inteiros, o curso do Ródano, desde o seu nascimento nas montanhas, passando pelo nome de cada um dos vales, pelo nome dos afluentes, pelas cidades em suas margens, tudo isto é tão grandioso e a informação tão épica, que eu sou absolutamente supérfluo.

Mas ninguém é capaz de ficar preso a este ponto de vista uma vida toda. Um dia, descobre-se também algo diferente perto do Ródano, perto dos vales e dos afluentes: descobre-se a si mesmo. Eu mesmo - esta é a mais fantástica e desconcertante experiência que um artista épico pode ter. Primeiro temse a impressão de que esta experiência é o começo da ruína. Mas o perigo e as dificuldades só rondam até o momento em que se percebe que a obra de arte é coisa do artista; não é o passado quem me dita as regras, eu mesmo dou as regras e, para mim, obra de arte épica significa outra coisa. Será que o autor pode interferir na obra épica, pode imiscuir-se nesse mundo? Resposta: sim, pode, deve e tem obrigação de fazê-lo. E, agora, lembro-me do que Dante fez na Divina Comédia: ele mesmo atravessou o seu poema, apalpou as suas personagens, intrometeu-se em seus casos, e não por brincadeira, senão com toda a seriedade; todos os do seu tempo o compreenderam no ponto mais importante do seu tribunal. Ele participou da vida de suas personagens. Como o rei David, ele também dançou diante do exército vitorioso de suas personagens.

Quando digo que também devemos ser líricos, dramáticos e reflexivos na épica, não estou dizendo para usar a palavra numa miscelânea de formas. Precisamos ir de novo ao núcleo original da obra épica, onde o épico ainda não se encontra imobilizado no procedimento específico de hoje, que nós, totalmente equivocados, consideramos como o modo normal do épico. Isto significa, a meu ver, ainda estar aquém de Homero.

Mas, em momento assim grandioso e perigoso, a questão é: poder e ser. Esta forma primordial da literatura vai revigorar a todos, que dela se aproximarem, mas vai haver 
muita desgraça. Só pode chegar às matrizes quem delas descende. É assim que vejo, um dia, surgir um poema épico que, depois de um bem sucedido rompimento com a tradição e depois de abandonar a forma do relato, nos possa dizer com sinceridade alguma coisa. Gostaria de exortar de novo e de novo os autores a não serem servos da forma, seja ela qual for, mas a se servirem dela.

E com isto elimina-se uma dificuldade específica e hoje muito pesada. Convido a fazer da forma épica uma forma bem livre, para que o autor possa seguir todas as possibilidades de representação que o assunto lhe pede. Se o tema se presta a dançar liricamente, há que deixá-lo dançar desse modo. Os autores percebem, em todos os lados, o chamado urgente da atualidade, de uma literatura atual. Com toda a honestidade, ainda hoje se diz: ninguém quer literatura, isso é uma coisa ultrapassada, a arte entedia, querem-se fatos e mais fatos.

Ao que replico "bravo!" e mais "bravo!” Não há nada que me arraste à fantasia. O coronel Springenau, no momento, deixa-me entediado. $\mathrm{O}$ verdadeiro poeta foi em todos os tempos ele mesmo um fato. O poeta tem de mostrar e provar que ele é um fato e um pedaço de realidade, e ainda tão bom e autêntico como a boa descoberta do triergon ${ }^{8}$ ou como a célula de Carolus. ${ }^{9}$ Os autores não tiveram que roubar fatos dos jornais nem que misturá-los em suas obras, isso é insuficiente. Correr atrás e fotografar não basta. Ser o próprio fato e criar espaço para isso nas próprias obras, é isto que faz o bom autor, e, por isso, exorto-o hoje a deixar cair a máscara obrigatória do relato e a mover-se na própria obra como julgar necessário.

(8) Döblin refere-se ao termo técnico usado para fazer referência à invenção da primeira filmagem e projeção do filme falado, cujos autores foram Hans Vogt, Jo Engel e Joseph Masolle.

(9) Döblin refere-se ao físico August Karolus (1893-1972), que desenvolveu, entre 1923 e 1924, a primeira forma de televisão com a ajuda de uma célula, por ele batizada de "célula de Karolus". 


\section{Diferença ENTRe O ATUAL MOdo DE PRODUÇão INDIVIDUALISTA E O COLETIVO DE OUTRORA}

Não tenho a intenção de resolver todos os problemas formais da épica, nem mesmo de tocar ou de mencionar os mais importantes. Não farei nada além de mover-me em torno das fortificações desse burgo, de lhe estudar os anexos e de aproximar-me dos portões de acesso. Pergunto, então, do lado de fora: que influências estão presentes na constituição da obra épica? Antigamente o poeta épico cantava, levando ao povo em seu redor as fábulas, as farsas e as lendas que circulavam entre o próprio povo e que, na maioria das vezes, eram pelo poeta pouco trabalhadas - devem apenas ter sido introduzidas, aqui e ali, algumas variantes ou uma nova melodia. O homem tinha, com isso, uma tarefa específica, tinha de ganhar a vida, seus ouvintes eram juízes rigorosos. Se não lhes agradava o que o autor apresentava, este ficava condenado a morrer de fome. É evidente que tudo isto exercia influência visível na configuração da obra; tratava-se da crítica mais produtiva e viva, a que se pode chamar diretamente de trabalho coletivo entre autor e público. O dinheiro e o pão eram um argumento fortíssimo para o autor e, indiretamente, um sólido fator a determinar a configuração da obra.

E agora? Agora o autor fica sentado em seu quarto, mordiscando o lápis ou a caneta, à espera de alguma idéia. Dinheiro ele também quer ganhar, mas aí os antigos cantadores e menestréis levavam a melhor: estavam em contato com seu público, percebiam rapidamente o que deviam fornecer. O autor de hoje pode ir à rua, pode falar com seu editor, ler os jornais, ouvir o que se diz aqui e acolá, mas não se pode falar de uma conexão sua com um círculo de ouvintes. Estamos todos sentados no banquinho da solidão, sem dúvida uma situação antipática e não compatível com a produção como um todo. A situação atual dos estados produto- 
res de cultura é propícia a criar por toda a parte autores individualistas, pois, as grandes associações, as grandes coletividades são, em nossos países, geralmente de ordem política e econômica; não existem coletividades poderosas em torno de idéias, pelo menos, quanto ao número de autores; neste sentido, em geral, não sopram bons ventos, nem para o grande teatro nem para a grande obra épica.

A tipografia é para o autor de hoje uma desgraça. Um livro é infinitamente comprido e pode-se aumentá-lo sempre mais, escrevendo dois livros, três. O que deve assinalar a um autor, a um autor épico, a hora em que deve parar? Na verdade, ele só precisaria parar quando se esgotasse todo o estoque de papel. E esta é, hoje, para nós a condição que falta à configuração de uma forma exterior. E como devemos nós falar, quem regula a nossa voz? De repente nem mesmo voz temos, a voz é-nos tirada e, em troca, dão-nos tristes letras impressas. Como poderiam as letras impressas exercer influência no ritmo de nossa fala? Onde está, justamente, o falar autêntico, o autêntico inspirar e expirar, a cadência da entonação que constroem a frase segundo seu sentido, e que ordenam as frases umas após as outras. E o que o autor hodierno deve escrever, para quem escreve afinal? Ele não sabe para onde vão os livros: talvez fiquem em Leipzig no depósito do editor; na realidade ele não fala para ninguém, fala no vazio, não há mais um pensamento coletivo do povo, a máquina e a economia destruíram tudo. Uma situação totalmente catastrófica.

Já não existem assuntos do agrado de todos, não há mais um pensamento popular palpável, e se há é bem rudimentar. A máquina e a economia despedaçaram tudo. Assim encontramos agora um autor dos dias de hoje, pobre, numa situação extremamente doentia, quase num anacronismo. Ele também quer ganhar dinheiro; sua pobreza não é anacronismo. Ora, o que acontece hoje, quando os autores perambulam solitários, ainda que vinculados a seus círculos? Como se processa, neste caso, a configuração de uma obra épica? Será 
que o autor se sente assim como um funcionário? Será que ele tem uma missão, que tem a ver com a constituição de sua obra? Será que alguém ainda o olha por cima do ombro? Vou descrever um processo de configuração hodierno.

\section{VI}

\section{Descrição Do ESTÁGIO DE INCUBAÇão NO ATUAL PROCESSO DE PRODUÇÃO ÉPICA}

Enquanto se anda por aí, executando o trabalho do dia a dia, enquanto se observam todas as coisas do cotidiano, algo, em determinado momento favorável, destaca-se no interior do autor, algo que se vai avolumando, que pede para ser dito em imagens. Segue-se um trabalho. Para ser mais exato, trata-se de um pensar sem pensamento. Coisas ocorrem secretamente, pode-se sentir, algo se move ou já se moveu. Todo o organismo, a alma entram em prontidão e isto agora, dependendo das circunstâncias, torna-se um estado particularmente tenso, melancólico ou selvagem. Digo que depende das circunstâncias, este é um ponto importante, pois a selvageria, a melancolia, a tensão mostram a atitude elementar daquilo que, agora, chega, que se vai revelar. É um sinal do processo interior que se estende ao comportamento geral do autor, não sempre, em algumas horas especialmente, e deixa-se trair através da mímica e de outras coisas. Neste passo, o autor ainda é idêntico à própria obra e este é o estágio sintomático, o estágio de incubação da produção, uma situação não esclarecida, portanto, em que a obra em preparação de certa forma ainda sobrepuja o autor, não está ainda suficientemente separada dele, uma situação em que a obra evidentemente suga e tira dele forças substanciais.

E agora vem o ponto que preciso apontar e introduzir, um ponto decididamente importante, e não se trata de um 
momento pessoal, senão de um momento que, de qualquer forma, vale para todos.Via de regra, primeiro vem o processo de incubação que consome um tempo longo, variável. Sentese que se é um tanto quanto absorvido por ele, com o que se deve ter cuidado. Não dou muita importância àquela comparação conhecida: o autor e sua obra tal qual mãe e filho, mas aqui no estágio de incubação ocorre uma espécie de estado maternal. Há que considerar aí duas instâncias: a instância que carrega e observa, que se inquieta facilmente e que coleta toda a espécie de alimento e a instância que é carregada. $\mathrm{O}$ eu pensante, consciente, recebeu a esta altura uma função bem específica. Falo do autor épico, e nos tempos hodiernos, ou seja, da função de coletar e de apresentar a matéria-prima e o material. O próprio indivíduo dirige-se, como um animal, ao comedouro e verifica se o pasto lhe apraz. Ocorrem rejeições, pode-se perder totalmente o rumo e, ocasionalmente, ao observar trabalhos épicos, tenho a impressão que, em si, há algo de bom e de correto nisso, mas acontece que o autor se equivocou quanto ao assunto, fez uma escolha infeliz, pois, é preciso sorte para achar o alimento certo. Sim, eventualmente, pode acontecer que ainda se esteja em trabalho de coleta, quando a situação interior já desapareceu. Neste caso, o autor comporta-se como uma galinha que chocou mal o seu ovo. E, então de repente, digo de repente, percebo que aí tem coisa.

Fico calado, li e ouvi isso e já o esqueci de novo e, agora, de repente salta-me algo aos olhos e eu sou, sem saber por quê, apanhado ou arrebatado de forma absurda, não, fico fascinado por um quadro. Não se trata de uma visão, nem de uma alucinação, mas de muitas coisas juntas, de um estado de alma marcado por uma claridade especial, não se trata de nada sombrio, mas de uma clareza de espírito rara, em que tudo aparece decifrado e em que se tem a sensação de Siegfried, quando lambe o sangue do dragão: entendem-se todas as línguas e todas as coisas. Mais ou menos como quando comecei um romance histórico, o Wallenstein. Num impulso nebulo- 
so, posso revolver documentos, folhear correspondências, apalpar, apalpar. O que está de prontidão em mim, beberica, beberica e, de repente, apresenta-se diante de mim a imagem de uma frota, não é uma visão, é algo mais abrangente, Gustav Adolf está cruzando o mar. ${ }^{10}$ Mas como ele cruza o mar? Há navios, galeões e fragatas que se destacam sobre as águas verde-cinzentas que produzem ondas de cristas brancas por sobre o Mar Báltico. Os navios cruzam o mar como cavaleiros, os navios balançam sobre as ondas como cavaleiros sobre o lombo dos cavalos, e estão arcaicamente carregados de canhões e de pessoas, o mar balouça por debaixo deles, dirigem-se à Pomerânia. É uma imagem fantástica, uma fascinação total. Sinto que isto acontece comigo. É como se eu tivesse puxado o fio de um novelo desordenado e, agora, tivesse encontrado o fim. Por causa deste estado sem par, estou decidido e sei que vou escrever e fazer um relato do sucedido; na realidade, para festejar, para louvar e para tornar público este estado, quero escrever um livro.

Essa abençoada iluminação imagética, esse instante carregado de saber são vivenciados pelo autor como sendo o momento da primeira concepção. Isto quer dizer que o que aconteceu no estágio de incubação se alargou tanto que ultrapassou uma determinada escala de valores e pode ser visto pelo autor. Em sua perspectiva, na perspectiva de quem? E estes são os dois pontos, que são importantes para nós neste estágio de incubação.

O primeiro ponto é: o todo alcançou um certo grau, uma certa abrangência, a alimentação foi boa, o animal alimentou-se de um certo pasto; é possível, então, chegar-se a uma imagem e a imagem passa a ostentar uma iluminação especial. E agora o eu, que até agora só tem tateado, recebe uma outra função, uma outra tarefa, e esta constitui o segundo

(10) Döblin refere-se ao estímulo desencadeador do romance Wallenstein, deflagrado por uma notícia de jornal em 1916 sobre um certo festival Gustav-Adolf. 
ponto. Agora o eu vê o que há diante de si, a quem alimentou no seu seio, por assim dizer. Observa esta criatura e toma posição perante ela. Ou dizendo sem rodeios: neste momento, o autor não está mais sozinho em seus aposentos, pensando ou chocando. Também não vai, como o antigo menestrel ou o contador de histórias atuar em meio ao povo, orientando-se pelos seus desejos. Mas, a partir desse instante, o autor passa a carregar o povo dentro de si.

Aquele eu observador assume, em nossos dias, o papel e a função que o povo desempenhava junto aos menestréis de outrora. O eu transforma-se em público, em espectador, por sinal, um espectador que interage. (Chamo a atenção para não o confundir com o "ouvinte ideal" de Goethe). A partir deste momento, instaura-se um trabalho de cooperação, um trabalho conjunto entre o eu e a instância poética. Este eu observador, pensante e avaliador está em constante ligação com a instância poética, espicaçando-a, fazendo-a recuar, alimentando-a ou dirigindo-a, bem ou mal - atua de modo regulador. Assim, não se fala de autor épico - e isto, com certeza, também vale para o autor dramático - não se fala de um impulso cego, liberto, de uma inconsciência que faz literatura. Inconsciente é somente o estágio de incubação; entretanto, de um modo singular, consciente, inebriado de idéias, com valores inerentes a todo o ambiente, à situação, à classe, à camada popular, ao senso de nacionalidade, o segundo estágio vai-se impondo. E todas essas coisas, pensamentos, valores do ambiente citado, constituem agora a obra, graças a um esforçado trabalho coletivo com a muito pessoal instância poética.

No mais, só para completar o quadro do processo da produção, ocorre aqui algo bem interessante. O eu consciente, pensante, nem sempre fica parado ao nível do público, do espectador e do colaborador; é introduzido, de forma particular, no processo de trabalho; a obra nascente repercute, de maneira sedutora no eu, repercute em alguns pontos, que exigem a libertação do eu; a obra enfeitiça o eu e, aí, podem sur- 
gir, sem interrupção do pensamento e da colaboração, duas situações: o eu, o colaborador, perde a sua postura de dirigente em relação à obra, coloca máscaras, suporta a sua obra, dança em torno dela. O eu é levado ao cenário da obra nascente e, pelo menos em parte, perde o controle. Com isto, o autor já fica mergulhado em profundo poetar obscuro (pense aqui na obra épica futura e dê voz a todas as profundidades. Tenha coragem, ouse, intrometa-se!). Embora a clareza geral perdure, a sua importância perante a obra tornou-se menos nítida; a própria obra ameaça, agora, deformar-se. Isto quer dizer apenas, logo percebemos, que carece de fórmula, mas existem formas mais profundas, e a obra torna-se literatura profunda.

$\mathrm{Ou}$, pode ocorrer a segunda situação, o segundo estágio do feitiço, o momento em que o autor não fica mais diante da sua obra, onde a obra engole o autor e o seu eu consciente: encontramo-nos, aqui, num estágio de concepção anônima de longa duração.

É o que acontece, por vezes, com a produção: grandes lapsos de clareza racional e de organização formal alinhamse numa primeira concepção, são trechos mais tranqüilos, preenchidos pela fantasia e, então, segue-se de novo o palpitar da concepção; tal qual um pilar, uma ilha, ergue-se em meio a um maremoto e, aí, surge novamente um ponto culminante e um novo ponto de partida. Há diversos tipos de autores. Nem todos irão compreender o que digo. Poetar, percebam, não significa só, como quer Ibsen, manter o dia do juízo final sobre si, também não significa apenas, como consideram os moralistas e os políticos, entre os autores, manter o dia do juízo final sobre si e sobre os outros. Significa ainda muito mais, significa, por exemplo, soltar-se, brincar, ter a coragem de sucumbir a feitiços interiores e ofertar-se a eles, em sacrificio, na forma e no conteúdo. 


\title{
VII
}

\section{DetalHes do PROCESSO DE PRODUÇÃo}

\author{
a) A obra Épica em STATU NASCENDI.
}

Quero dirigir o olhar à continuação do processo de formação e descrever a repercussão de alguns fatores formais. Inúmeras vezes, começa-se uma obra épica como um nadador que se atira ao mar. O indivíduo não conhece a extensão do mar, confia, entretanto, em suas forças e tem vontade de nadar. É indiferente se se põe a escrever ou se constrói um cenário para contrabalançar as suas forças. Tem-se uma concepção inicial e um sentimento geral básico obscuro, a ordem agora é ir em frente e agarrar-se à situação central que ainda não é clara. Minhas senhoras e meus senhores, a maioria das obras épicas é começada assim, num impulso obscuro, e o rosto da obra só vai se desvelar durante o trabalho. Acreditase que o autor lhe relate e lhe escreva o que ele sabe. Não, ele não sabe nada ou quase nada, ele se atira, fazendo uma idéia e com a intuição de suas forças, numa aventura. Escrevendo, chega-se ao tema. O leitor, portanto, participa com o autor do processo de produção. Todas as obras épicas têm a ver com o vir-a-ser e com o acontecer. Gostaria de dizer que isso está certo, que o relato épico não nos é apresentado de forma acabada, sibilando disparado de um revólver. Ao contrário, o leitor vivencia-o em statu nascendi.

É preciso saber que, em todas as obras épicas de maior abrangência, nenhuma delas é apresentada redonda, fechada, perfeitamente completa. Nelas, assiste-se à geração, ao desenvolvimento e ao crescimento da obra de arte, diferentemente das obras decorativas e, provavelmente, de algumas obras dramáticas. Mas também estas, pelo menos, também possuem algo disto e, por sinal, não o pior. É o que também acontece com as grandes obras das outras artes, como a música: os temas não se desenvolvem uns a partir dos outros 
apenas pela sua musicalidade, mas também em relação ao tempo; eles nascem no momento preciso. E isto dá-lhes, assim como também à realização épica, não só um encanto especial, mas também o estatuto de uma verdade peculiar, de veracidade e transparência, pois quando vemos como algo surge diante de nós, nós lhe conferimos de modo extremamente fácil a categoria de verdade e ela nos convence. Esta é a regra da causalidade específica no épico.

Esse investimento, diante de nossos olhos, também tem a vantagem de conduzir, igual e simultaneamente, autor e ouvinte de surpresa em surpresa e, naturalmente, de encanto a encanto. Tem a vantagem de possibilitar a cada situação gerar, de modo natural, a próxima. De resto, tem nisso sua razão de ser, sendo este jeito de configurar necessário, porque nunca se pode prever esteticamente, em um espaço maior, qual será a tensão exigida aqui e ali. Grosso modo, pode-se delimitar a moldura do todo, mas se se fizer mais, se os pilares forem colocados mais próximos uns dos outros, então o esboço ficará comprometido, pois tal pilar pode não se ajustar ao lugar acercado.

\section{b) A obra épica é Ilimitada Pela sua constituição}

Continuo salientando uma característica geral da obra de arte épica: sua ilimitabilidade. Esta é uma característica toda especial numa forma artística, esta lei da negação da forma; ela existe, não se deixa desmentir, e é preciso observála com atenção, pois é uma característica assaz essencial e, aqui, nós nos encontramos no mais genuíno terreno do épico. Exteriormente, a questão hoje apresenta-se assim: é dada ao autor épico a forma do livro, mas um livro é, na verdade, um começo, mas nunca um fim. É assim que preciso começar, e o bom Deus tem que me ajudar a terminar. Se alguém me disser para falar uma hora, terei de me adaptar a isso e serei 
empurrado a fazer um determinado esboço. Mas hoje, no épico, haveria apenas uma possibilidade para se chegar a uma forma externa fechada, a saber, se o editor racionasse o número de páginas. Esta mesma característica, da forma ilimitada, se é que se pode dizer algo assim, também se impunha no tempo dos antigos contadores de histórias. Esta característica é, na verdade, também interna ao épico. Os poemas épicos antigos dificilmente tinham um começo e, com certeza, não tinham um final. Um indivíduo terminava hoje de contar e amanhã ele continuava contando, as pessoas querem ouvir algo novo, mas não havendo muita matéria disponível enquanto o interesse cresce, liga-se o novo ao que já se contou, faz-se então um trabalho de seriado, trabalho em série, continuações sem fim. No teatro uma pessoa morre de uma vez, depois de duas horas; o autor épico é mais suave, deixa morrer hoje, mas amanhã pode ressuscitar de novo. Este é o método épico correto, a produtividade da situação ou das personagens é característica, e você não precisa deixar-se enganar pela nossa pseudo-épica de hoje, os romances, que tolamente imitam o teatro - da maioria dos romances hodiernos é possivel extrair algo como uma peça de teatro. Este é o sinal de que seu fundamental princípio formal é falso. Essas situações e personagens esgotam-se em duzentas páginas. Repare no Dom Quixote de Cervantes: talvez se possa fazer da luta de Dom Quixote contra os moinhos de vento uma peça de teatro; é dificil, mas ainda assim, possivel. Todavia, a obra épica como um todo, o livro Dom Quixote, não é passivel de ser transformado em peça de teatro, pois aí acontece cem vezes, sempre de uma forma renovada, a mesma coisa: Dom Quixote está sempre lutando contra um novo tipo de moinho de vento e isto, para Cervantes, é suficiente. É fortuito e superficial o fato de Dom Quixote ter de morrer. Para Cervantes o assunto havia acabado, então, deixou Dom Quixote morrer. Cervantes já era individualista, mas teria sido possivel aos seguidores continuarem, sem problemas, fazendo poesia sobre esse assunto fantástico. A característica da forma ilimita- 
da, que se nos impôs na constituição formal, acha, portanto, justificação interna e externamente.

\section{c) Dinâmica e proporção COMO Leis formais E CO-CRIAdoras DO CONTEÚDO}

Agora, observo simultaneamente uma tendência contrária, uma outra obra em algumas obras épicas, ou seja, obras que conseguem chegar à forma fechada. Mas, só em certo sentido, estas duas características se opõem. Cada produto épico requer, é claro, como Dom Quixote, um fecho, um final e, por isso, a forma fechada. Na verdade, porém, a obra épica não tem limites; ela é, neste sentido, desprovida de forma. Mas a obra tomada isoladamente confere à épica sem limites um fim e elabora para si, neste peculiar caso concreto, princípios e leis formais específicos. Suponham que pretendo descrever uma convulsão revolucionária de um determinado povo, e impõe-se a mim como início uma cena vivida, um assalto a um funcionário público de alto escalão, uma cena noturna. Isto será perfeitamente compreendido como introdução, como uma espécie de rufar de tambores abafado, uma descarga única, vivida, sobrevindo depois o silêncio. Todos os pontos em particular virão a destacar-se a partir do tom estabelecido pela introdução turbulenta e sinistra. Neste momento, já estou familiarizado com o que virá: uma ação colossal, com certeza, senão as proporções não conferem, e uma certa dinâmica também se fará presente. Haverei de começar devagar, com amplitude, talvez com uma personagem apenas, para chegar a um maciço crescendo. Estas proporções, esta dinâmica, estas tendências formais, são percebidas com vivacidade e, se agora a fantasia trabalha e se, incansavelmente, busca material, é porque aqui temos, então, a lei máxima e o quartel general, de onde provêm as diretrizes determinantes, esta lei formal para um empuxo lento e amplo. E, assim, depois de ter puxado, como que por um fio, uma única personagem, passo a 
lançar, então, as demais, uma após a outra, para dentro do processo, até atingir um determinado clímax.

Foi com um rufar de tambor assim que comecei um romance chinês, ${ }^{11}$ com um rufar abafado de revolução subterrânea. E, então, por motivos puramente formais, quero dizer musicais, começo pelo relato acerca de um homem, relato este que passo a tecer de maneira ampla, e este homem deve tornar-se, assim, o fio da meada, a que outros fios se acoplam e, desta forma, vou agrupando em torno dele uma personagem atrás da outra; estimulo-o a agir, a fim de que mais e mais personagens se agreguem em torno dele, fazendo dele o herói, o motor dessas movimentações; acrescento ainda, a título de uma maior expansão, mais alguns episódios e, finalmente, estabeleço de modo puramente artístico o início do meu livro. Isto é, fui obrigado a estabelecê-lo assim. Aquela vontade determinada, dirigida à dinâmica e à proporção, uma tendência musical, tendência de uma música arquitetônica, exigiu e gerou aquelas personagens, o seu agrupamento e a sua movimentação. A lei da forma, devo dizer, realmente produziu o conteúdo, de modo concreto, tal como aparece. Todavia, o tema épico era: alguém luta em vão, sem violência, contra a violência, um herói fraco, aquele que é verdadeiramente fraco.

Pego um outro trecho. O movimento revolucionário no país atinge um ápice estarrecedor. As cores deste cenário tornam-se insuportavelmente vívidas; são reclamados tons serenos e comemorativos. É possivel, então, que já não precise do meu herói. Permito-lhe uma reclusão interior, e ele abandona o grupo, desaparece no país. Mas para os grandes tons comemorativos é preciso procurar pessoas e criar ação. É aí que surge o papa tibetano, e, então, torna-se necessário procurar

(11) Döblin refere-se a seu romance Die drei Sprünge des Wang-lun, cuja primeira versão, de 1912, continha este capítulo inicial, retirado da versão publicada em 1916 e transformado, em 1921, no conto Der Überfall auf Chao-lao-Sü. 
por um cenário totalmente diferente e muito austero. Descreve-se este cenário: mosteiros, a terra gelada do Tibet e a pomposa chegada do papa às terras da China para um encontro com o grande imperador da Manchúria. Diante de todos os detalhes impõe-se, porém, a estrutura em capítulos. É o plano básico.

Neste mesmo capitulo, nos pormenores, nos detalhes, repercute ainda o mesmo esquema formal. A partir de certos pontos, trechos inteiros são percebidos antecipadamente, mas trata-se de trechos vazios de conteúdo, necessários apenas em função da sua dinâmica, e talvez de seu tamanho. É nesta câmera de ar que a fantasia irrompe e a preenche. Gostaria de falar em uma rede de tensão, em uma rede dinâmica, que se estende por toda obra, que se fixa em certas concepções, e, nesta rede, são encaixadas ações e personagens. Reconhecese, aqui, que obras épicas deste tipo não se parecem nem com o antigo modelo épico ilimitado, nem com o tipo de romance dramático moderno ruim. Falo aqui de um tipo de obras de arte épicas modernas, em desenvolvimento, que trazem em si leis formais bem definidas. Dei exemplos fáceis de serem analisados em meus próprios livros.

Se se perguntar com que se parecem, então, essas obras de arte, essas obras com tais leis formais, a exposição feita até aqui já o mostrou: parecem-se com obras sinfônicas. Também é compreensivel que as duas artes temporais, a música e a literatura, ao refletirem o seu caráter artístico, tenham um certo número de pontos comuns.

\section{VIII}

\section{A linguagem no PROCESSO DE PRODUÇão}

Por fim, descreverei a função da linguagem dentro do processo de produção. 
Tão logo a concepção é captada, ocorre uma situação surpreendente, uma situação de perplexidade. O autor precisa falar, ou seja, escrever, ele gostaria de falar, ou seja, de escrever e, aí, acontece a surpresa, já muitas vezes observada: percebe-se (alguns percebem), penetra-se (alguns penetram), neste momento em que se fala ou que se escreve, em um mundo totalmente diferente, digamos em um outro plano espiritual. Concepção não é mais concepção; de qualquer modo, é o que constata um certo número de autores. A coisa transformou-se no momento do falar, no do escrever, mas a coisa ainda é muito simpática, embora não mais tão imponente. Portanto, a incorporação da concepção ao corpo lingüístico causa uma mudança substancial, em parte destrutiva, podemos dizer sem receio. Estes autores, agora, sentem, no que está escrito, falta da originalidade, da singularidade de sua concepção, e não se sentem muito satisfeitos com a linguagem. Talvez estes autores tenham concepções e intuições de um tipo bem específico. Para outros autores, inclusive para mim, as coisas são bem diferentes.

Estou satisfeito com a linguagem. Ela me presta extraordinários favores proficuos; no meu trabalho, comporta-se como a mais útil das ajudantes. Há variadas relações e ligações entre a concepção e a linguagem. Para aqueles que consideram a concepção materializada na escrita uma desilusão, a linguagem é evidentemente um instrumento, uma ferramenta, matéria, em que se depositam as idéias e as fantasias vindas de outro lugar. Mas também se pode experimentar a linguagem de outra forma e, então, ela pode ser outra coisa. Exponho minha própria observação: há idéias que são indizíveis. Devemos nos precaver de transformá-las imediatamente em escrita, se não quisermos vivenciar o processo de desilusão. As coisas querem amadurecer; a idéia logo construirá o seu corpo lingüístico. E, então, de repente, chega-se ao ponto, em que, a partir desta situação se consegue formar uma única frase. Captura-se, assim, de certa forma o animal pela cauda e este, agora, não escapará mais. Porém, de fato, a 
situação escrita continua diferente, não é idêntica à da concepção, mas é mais rica, mais concreta, mais viva! E, sobretudo, no épico, continua estimulante. É possivel até que a concepção já carregue em si movimento, mas o texto escrito, o enfileirar das frases, a melodia recentemente composta não dão sossego. E quão mais rico e valioso é o texto escrito, tão rico e valioso que, ao final, a concepção acaba ressoando apenas como um baixo contínuo.

Mas também pode acontecer e, com certeza, parecer notável, o fato de, simultaneamente, à concepção ideal suceder uma determinada concepção lingüística. Não se trata de nada sobrenatural, mas de algo semelhante ao sonho, em que, eventualmente, alguém ouve ressoarem algumas palavras e frases.

E há ainda uma terceira possibilidade a considerar: é possível que nem se tenha uma concepção ideal, e sim que ocorram algumas frases, sabe Deus a partir de que contexto, e esta é para o autor, dentre todas, a melhor das situações. Era assim que, há pouco, eu falava da viagem de Gustav Adolf pelo Mar Báltico. No entanto, esta concepção ficou muda e não rendeu nada. Eu também temia pronunciá-la. Então durante o trabalho, enquanto lia sobre os cargos na corte do imperador Ferdinando II, ocorreu-me uma frase, que era uma concepção lingüística. E uma tal concepção lingüística só se compara àquelas puramente ideais e, para o autor épico, o artífice da língua, é, dentre todas, a mais importante. A frase era: "Depois que os boêmios haviam sido derrotados, ninguém ficara mais alegre do que o imperador. Ainda não tinha..."; a frase não continuava. Mas era ótimo, era o início do meu livro; a melodia e o ritmo estavam ali; podia começar, nada mais podia me acontecer. Se tivesse que descrever a relação entre concepção e linguagem, diria que a concepção é o puro texto de uma canção, a linguagem é a canção, a música. Portanto, a linguagem é da maior importância para a "concepção", pois a canção não estará pronta sem a melodia correta. 
Assim como para o poeta não pode haver nada mais importante do que a composição musical correta de suas palavras, assim também para o autor épico, não há nada mais importante do que a ligação íntima entre seus pensamentos, suas idéias e a linguagem. Assim como a linguagem mal escolhida pode estragar a idéia, a linguagem selecionada, a linguagem bem concebida pode poupar metade do trabalho, até mesmo na improvisação, na invenção. A linguagem bem escolhida conduz corretamente, conduz, no sentido de concepção original, a novas idéias, é em si uma força produtiva. O maior perigo formal para o autor épico consiste em passar para um nível errado de linguagem. Seria um trabalho abençoado, tanto para o autor quanto para o leitor, se os filólogos produzissem um léxico dos estilos lingüísticos alemães e dos níveis de linguagem. Poderia ser um trabalho muito importante para a instrução de autores e para a intimidação de diletantes. Não temos, em alemão, um número assim tão grande de estilos e de níveis lingüísticos identificáveis. Temos a linguagem de conversação, diversificada nas diferentes camadas sociais, e também nas províncias, não apenas em decorrência dos dialetos. Existe o nível lingüístico das pessoas ligadas aos jornais, dos corretores de bolsa e de outras profissões. Mas estes, infelizmente, não interessam muito aos autores, infelizmente; seria desejável, no entanto, que os autores mergulhassem mais intensivamente na vida desses homens. Para os autores, porém, são de grande importância os estilos escritos como, por exemplo, o estilo do tradutor da Bíblia, Lutero. Esse estilo sobreviveu a gerações inteiras, tem hoje em dia um certo nível literário, ocupa um certo plano intelectual; mas quem pisa nesse nivel, precisa saber onde está pisando, precisa saber para onde essa linguagem o leva, e saber que a escolha leva, não só de algumas frases a outras frases do mesmo nivel, mas também impele a pensamentos e a representações subjacentes a esse nivel. Em outras palavras: em cada estilo lingüístico mora uma força produtiva e uma natureza coercitiva, a saber, uma natureza coercitiva formal e uma natureza coercitiva ideal. 
Os diletantes aproveitam-se disso e, facilmente, poetam em tal plano; não percebem, contudo, que mal estão inseridos no jogo, não percebem que estão em jogo autonomia lingüistica e autonomia ideal; acham que só precisam introduzir uma moedinha na máquina automática, que a máquina logo ronrona. Mas o verdadeiro autor também se arrisca; sabe, porém, o que estou dizendo: ou se acredita estar escrevendo, quando na verdade alguém fala, ou se acredita estar escrevendo, quando na verdade alguém escreve. E, para continuar falando do nosso léxico, do estilo lingüístico e dos valores intelectuais correspondentes, temos ainda que considerar o estilo jâmbico de Schiller, a prosa tardia de Goethe, a prosa de Heinrich Heine, que até hoje é cultivada nos folhetins, o estilo clássico de Platão e outros. Todos estes estilos lingüísticos guarnecem um plano intelectual e, por isso, repercutem simultaneamente de modo produtivo e instrutivo - por outro lado, e em especial no que diz respeito a autores independentes, repercutem de modo catastrófico, devastador e redutor. Apenas o leigo acredita que existe uma única língua alemã e que se pode, a bel prazer, pensar dentro dela. O conhecedor sabe que existe um bom número de níveis lingüisticos, em que tudo se movimenta. Quem quiser ser intelectualmente independente, quem quiser dizer algo poeticamente original, corre grande perigo e está em risco. É bom saber deste perigo, e não é novidade que, quando se quer dizer algo original, tanto intelectualmente, quanto pelo viés da fantasia, deve-se primeiro afastar os modelos lingüísticos antigos para, depois, cantar ao seu próprio modo.

No que se refere à força modeladora da língua, como mostra o que já foi dito, há que considerá-la como uma força produtiva geral, simultaneamente de caráter formal e ideal, e é assim que ela se mostra tanto no ato de escrever pensando, quanto no ato de pensar escrevendo, como o movimento de frase a frase, de período a período. De quando em vez surgem mais regras rítmicas, de quando em vez um maior número de aliterações parece tomar as rédeas, de vez em quando apare- 
cem mais tons semelhantes. O caráter ideal neste plano luta com o caráter lingüístico naquele outro. Quem vence é sempre a língua, não o bom autor. Quem não experimentou isso, não conhece o motivo básico da linguagem viva, que não é a linguagem da filologia, nem do léxico. Trata-se, isso sim, de um fenômeno concreto, florescente, que não conhece palavras, da mesma forma que o mundo não conhece objetos isolados; um fenômeno que escoa em palavras e frases, claro e farto de idéias; que vive e sente. De resto, pode-se dizer muita coisa sobre a separação banal entre prosa e poesia, entre linguagem prosaica e linguagem poética. No verdadeiramente épico, no entanto, essa separação inexiste para quem olha com perspicácia.

Agora, quero parar de falar da linguagem, de sua força produtiva no plano formal e no plano intelectual, de seu caráter coercitivo. Também não quero falar sobre o fato de que considero a libertação da obra épica do livro dificil, mas necessária, útil principalmente no que concerne à linguagem. O livro é a morte da verdadeira linguagem. Ao autor épico, que só escreve, escapam as principais forças modeladoras da linguagem. Há muito venho dizendo: distância do livro, mas não vejo um caminho nítido para o autor épico de hoje, a não ser o caminho para um novo palco. E isso bate na mesma tecla do que já disse da renascença e da regeneração da obra épica.

Afinal, o que faz uma obra ser épica? A capacidade de seu criador de penetrar fundo na realidade, de atravessá-la, para atingir as grandes situações básicas, simples e elementares, bem como as personagens da existência humana. A isto acrescente-se a impetuosa arte de fabular do autor, para compor a obra da palavra viva. E, em terceiro lugar, derramese tudo na corrente da linguagem viva, que o autor acompanha. 